Jurnal Ilmiah Sport Coaching and Education Vol. 3 Juli 2019

\title{
HUBUNGAN ANTARA PANJANG TUNGKAI DAN DAYA LEDAK OTOT TUNGKAI TERHADAP HASIL LARI 100 METER ATLET ATLETIK
}

\author{
Dewi Rahmawati \\ Bambang Sujiono dan Ika Novitaria Marani
}

Fakultas Ilmu Olahraga Universitas Negeri Jakarta

\author{
Email : dewirahmawati27@gmail.com \\ bambangsujiono@unj.ac.id dan ikanovitaria@unj.ac.id
}

\begin{abstract}
ABSTRAK
Tujuan dari Penelitian ini adalah untuk dapat mengetahui hubungan panjang tungkai dan daya ledak otot tungkai terhadap hasil lari 100 meter pada klub atletik Jakarta Utara. Metode yang digunakan dalam penelitian ini adalah metode survey dengan Teknik studi korelasional. Populasi dalam penelitian ini adalah para anggota klub Atletik Jakarta Utara dengan jumlah atlet 50 atlet. Jumlah sampel sebanyak 30 orang, sampel ditentukan dengan Purposive Sampling. Hasil penelitian menyimpulkan bahwa: (1). Terdapat hubungan Panjang Tungkai dengan hasil lari 100 meter diperoleh koefisien korelasi ry1 $=0.69$, yang berarti variabel panjang tungkai memberikan sumbangan terhadap hasil lari 100 meter sebesar $82.38 \%$. (2). Terdapat hubungan yang berarti antara daya ledak otot tungkai dengan hasil lari 100 meter, diperoleh koefisien korelasi ry $2=0,94$ yang berarti variabel Daya Ledak Otot Tungkai memberikan sumbangan terhadap hasil lari 100 meter sebesar $88.50 \%$. (3). Terdapat hubungan berarti antara Panjang Tungkai dan Daya Ledak Otot Tungkai dengan hasil lari 100 meter secara Bersama - sama, dengan koefisien korelasi ganda Ry1-2 = 0,94 hal ini berarti bahwa 88.50\% Hasil Lari 100 Meter ditentukan oleh Panjang Tungkai dan Daya Ledak Otot Tungkai secara bersama-sama.
\end{abstract}

Kata Kunci : Panjang Tungkai, Daya Ledak Otot Tungkai, Hasil Lari 100 Meter.

\section{ABSTRACT}

The purpose of this research is to find out relationship between leg length and leg muscle explosiveness to the results of running 100 meters at the North Jakarta athletic club. The method used in this study is a survey method with correlational study techniques. The population in this study were the members of the North Jakarta Athletics Club with 50 athletes. The number of samples is 30 people, the sample is determined by purposive sampling. The results of the study concluded that: (1). There is a relationship between the length of the limb with the result of running 100 meters and the correlation coefficient is ryl $=0.69$, which means that the leg length variable contributes to the 100 meter run by $82.38 \%$. (2). There is a significant relationship between the leg muscle explosive power with the result of running 100 meters, the correlation coefficient ry $2=$ 0.94, which means the variable Explosion of Leg Muscle contributes to the 100 meter running result of $88.50 \%$. (3). There is a significant relationship between Leg Length and Leg Muscle Explosion with the results of running 100 meters together, with a double correlation coefficient Ry1-2 = 0.94 this means that 88.50\% 100 Meters Run Results are determined by Leg Length and Muscle Explosion Power. Limb together.

Keywords: Leg length and leg muscle explosive power, results of 100 meters run. 


\section{PENDAHULUAN}

Lari cepat atau sprint 100 meter yaitu perlombaan lari yang semua peserta berlari dengan kecepatan penuh dengan menempuh jarak 100 meter. Untuk mencapai hasil yang maksimal dalam lari 100 meter diperlukan penguasaan teknik start, teknik berlari, dan teknik melewati garis finish. Dalam melakukan gerakan lari 100 meter, yang terkait dengan gerakan utama adalah panjang tungkai dan daya ledak otot tungkai. Tapi hal tersebut tidak akan lepas dari latihan yang baik dan teratur, jika ingn mencapai hasil yang maksimal.

Struktur tubuh mempunyai andil yang tidak kalah pentingnya dalam pencapaian prestasi olahraga. Misalnya saja dengan panjang tungkai yang memadai serta keserasian dengan kekuatan otot tungkai akan lebih baik dalam cabang olahraga tertentu. Struktur tubuh yang dimiliki seseorang mempengaruhi setiap aktivitas nya dalam olahraga, karena struktur tubuh yang dimiliki biasanya dihubungkan dengan kemampuan atau kekuatan fisik yang dimilikinya.

Lari cepat 100 meter merupakan salah satu nomor lintasan dari cabang olahraga atletik. Kebanyakan orang memiliki kecepatan maksimal di mana energi kinetik seimbang. Orang dengan tungkai pendek membutuhkan lebih banyak langkah untuk menempuh jarak yang sama dengan orang bertungkai panjang. Dengan kata lain orang yang tinggi memiliki langkah yang lebih panjang.Orang dengan langkah panjang bisa berjalan lebih cepat daripada orang-orang dengan langkah pendek jika mereka mengambil jumlah langkah yang sama per menit karena mereka dapat menempuh jarak lebih jauh dalam setiap langkah kaki mereka. Tapi ada yang mengatakan bahwa kaki yang lebih pendek tidak menjadi alasan kecepatan berjalan yang lambat.

Sehubungan dengan tuntutan teknik dasar dalam atletik khususnya nomor lari 100 meter maka terlihat dengan jelas bahwa unsur struktur tubuh sangat dibutuhkan, terutama dalam gerakan berlari tersebut serta untuk mendapatkan hasil yang baik dan terarah diantaranya adalah: tinggi badan, berat badan, lingkar paha dan panjang tungkai.

Dapat dirangkum dugaan bahwa perpaduan Panjang tungkai dan daya ledak otot tungkai mampu menghasilkan kecepatan maksimal yang baik. Atlet yang tidak memiliki Panjang tungkai dan daya ledak otot tungkai yang baik akan kesulitan meningkatkan prestasi lari nya dan hasil lari yang baik dan maksimal. Untuk membuktikan secara ilmiah maka peneliti mengadakan penelitian dengan judul " Hubungan panjang tungkai dan daya ledak otot tungkai terhadap hasil lari 100 meter klub atletik Jakarta Utara “.

\section{Lari 100 Meter}

Pada dasarnya gerakan lari pada semua jenis lari sama, gerakan berpindah dengan kaki dari satu tempat ke tempat lain untuk mencapai tujuan. Menurut Mujahir (2007: 121) menjelaskan bahwa: sprint atau lari jarak pendek adalah perlombaan lari yang semua para pelarinya dengan kecepatan yang sangat penuh dengan menempuh jarak 100 meter, 200 meter, dan 400 meter.

Muhtar (2011: 12) menjelaskan bahwa : Lari jarak pendek (Sprint) merupakan suatu cara untuk berlari dimana si atlet harus menempuh seluruh jarak dengan kecepatan semaksimal mungkin. Artinya harus melakukan lari yang secepat- cepatnya dengan mengerahkan seluruh kekuatannya mulai awal (start) sampai melewati garis akhir (finish). Disebut dengan lari cepat karena jarak yang ditempuh adalah pendek atau dekat. Mengingat dalam lari ini yang diutamakan adalah kecepatan maka kekuatan fisik yang prima sangat diperlukan. Lari sprint sangat mengutamakan daya ledak otot kaki, makin cepat larinya maka makin panjang pula langkahnya.

Pelari jarak pendek harus memperoleh kecepatan tinggi dalam waktu sesingkat mungkin agar berhasil dalam perlombaan. Untuk itu, pelari harus memiliki start yang baik, mampu menambah kecepatan, dan mempertahankan kecepatan maksimum untuk jarak yang tersisa. Gerakan 
lari sprint menggunakan ujung kaki untuk menapak, sedangkan tumit hanya sedikit saja menyentuh tanah pada permulaan dari tolakan kaki. Yang harus diperhatikan juga adalah berat badan pelari harus selalu berada sedikit di depan kaki pada waktu menapak, atau dalam posisi badan condong ke depan. Menurut Munasifah ( 2008 : 5) menjelaskan bahwa: Tumpuan kaki pada saat memiliki peranan penting dalam kecepatan lari, karena semakin luas penampang kaki yang menapak maka akan mengurangi kecepatan lari.

Gerakan keseluruhan dalam melakukan Teknik gerakan lari terdapat tiga fase yaitu fase topang (support phase) yang dibagi menjadi fase topang depan dan satu fase dorong. Kemudian fase melayang (flight phase) yang dibagi lagi menjadi fase ayun depan dan satu fase pemulihan. Dan terakhir kembali ke fase Topang (Support Phase).

\section{Panjang Tungkai}

Panjang Tungkai adalah anggota gerak bagian bawah yang terdiri dari paha, betis dan kaki. Ukuran panjang tungkai adalah jarak antara ujung tumit bagian bawah sampai dengan tulang pinggang. Tungkai merupakan organ yang paling berperan dalam lari cepat (sprint), karena pergerakan lari yang dihasilkan berasal dari kekuatan yang dihasilkan oleh otot tungkai. Kecepatan berlari ditentukan oleh dua aspek, yaitu panjang langkah dan frekuensi langkah. Tungkai pada tiap individu mempunyai ukuran yang berbeda beda sehingga berpengaruh terhadap perbedaan kecepatan lari tiap individu. Semakin panjang tungkai seseorang memungkinkan seseorang dapat melangkah secara lebih panjang dan lebih efisien dalam menempuh jarak yang diperlombakan. Otot betis yang lebih panjang rata-rata lebih kuat dibandingkan yang pendek. Menurut M. Sajoto ( 1998 : 111) menjelaskan bahwa: Apabila seorang pelari memiliki otot yang lebih panjang tidak menutup kemungkinan lebih besar kekuatan otot yang dimiliki.

Panjang otot sama pentingnya dengan panjang tulang, semakin panjang otot semakin panjang tulangnya, kemungkinan juga besar pula kekuatan yang dihasilkan. Sehingga panjang tungkai sangat diperlukan bagi seorang pelari. Panjang tungkai sebagai salah satu anggota gerak bawah memiliki peran penting dalam untuk kerja olahraga. Sebagai anggota gerak bawah, panjang tungkai berfungsi sebagai penopang gerak anggota tubuh bagian atas, serta penentu gerakan baik dalam berjalan, berlari.

Menurut James G. hay (2002 : 92) menjelaskan bahwa: Panjang tungkai yang dipergunakan dalam bidang olahraga adalah jarak antara telapak trochanter mayor yang terdapat pada tulang paha bagian atas sampai telapak kaki pada sikap berdiri tegak. Panjang tungkai dilihat dari Antropometrik merupakan tungkai yang dimiliki seorang yaitu jarak antara trochanter mayor atas terhadap tulang pangkal paha sampai telapak kaki.

Sugianto (1991: 301) menjelaskan bahwa:Tungkai sebagai batang pengungkit menerus sistem mekanis: semakin otot pergerakannya kuat dan semakin Panjang batang ungkitnya akan menghasilkan kemampuan gerak yang baik. Menurut Hidayat (2004: 50) Pengukuran panjang tungkai dapat dilakukan dengan cara :"setelah teste berdiri tegak, diukur tinggi badan, tinggi duduk, maka panjang tungkai tidak perlu diukur melainkan hanya mengurangi tinggi badan dengan tinggi duduk".

Seorang olahragawan yang memiliki proporsi badan tinggi biasanya diikuti dengan ukuran tungkai yang panjang, meskipun hal itu tidak demikian, ukuran tungkai yang panjang tidak selalu memberikan keuntungan dalam jangkauan langkahnya hal ini dikarenakan kelincahan masih dibutuhkan.

\section{Daya Ledak Otot Tungkai}

Olahraga atletik merupakan olahraga yang melibatkan semua anggota tubuh dan membutuhkan komponen fisik untuk dapat melakukan gerakan secara eksplosif khususnya untuk nomor sprint. Sesungguhnya yang dibutuhkan dalam cabang olahraga atletik bukan hanya 
kekuatan saja, akan tetapi kekuatan yang disertai unsur kecepatan yang disebut dengan istilah daya ledak ( power). Menurut Tudor O Bompa (2009: 233) menjelaskan bahwa: Daya ledak adalah hasil kali antara kekuatan dan kecepatan. Maka kedua komponen ini perlu diperhatikan terlebih dahulu dalam pelaksanaan program latihan untuk membentuk daya ledak.

Daya ledak otot tungkai merupakan kondisi fisik yang sangat erat kaitannya terhadap seseorang yang sering menggunakan otot - otot tungkainya untuk melakukan aktivitas atau menerima beban. Seperti halnya dalam olahraga lari 100 meter khususnya dalam melakukan awalan, tanpa adanya dukungan daya ledak tungkai yang baik mustahil seorang pelari akan mampu menghasilkan lari yang cepat dan tepat. Oleh sebab itu salah satu jenis daya ledak yang perlu dikembangkan pada seorang atlet lari adalah unsur fisik daya ledak otot tungkai. Dengan demikian orang yang memiliki daya ledak otot tungkai yang besar akan sangat besar pengaruhnya bagi seorang pelari cepat. Dengan kata lain seorang pelari yang mempunyai daya ledak otot tungkai yang besar akan mempunyai keuntungan diantaranya pada saat menumpu dan pada saat melangkahkan kakinya kearah horizontal. Untuk mengembangkan daya ledak otot tungkai siswa/atlet dapat dilakukan dengan meningkatkan komponen kekuatan dan kecepatan dengan cara atlet melakukan lompat tanpa awalan (standing board jump).

Berdasarkan pada beberapa pendapat tersebut di atas, dapat dijelaskan bahwa unsur daya ledak diperlukan dalam berbagai olahraga. Khususnya olahraga lari jarak pendek, daya ledak diperlukan dalam rangka untuk mempercepat gerakan kaki agar kecepatan yang dihasilkan bisa maksimal. Dapat ditarik suatu pengertian daya ledak otot tungkai adalah suatu kemampuan untuk melakukan aktivitas secara kuat dan cepat untuk menghasilkan tenaga otot tungkai.

\section{METODE PENELITIAN}

Penelitian ini dilaksanakan di Stadion Tugu Jakarta Utara Jln. Jamrud No. 76A, Tugu Selatan, Koja, Kota Jakarta Utara. Waktu penelitian ini dilakukan pada tanggal 10 Februari 2019 untuk tes Panjang Tungkai, Daya Ledak Otot Tungkai, dan hasil Lari 100 meter.

Metode yang digunakan dalam penelitian ini adalah metode survey dengan Teknik studi korelasional. Populasi dalam penelitian ini adalah para anggota klub atletik Jakarta Utara dengan jumlah 50 atlet. Jumlah sampel sebanyak 30 orang, sampel ditentukan dengan Purposive Sampling.

\section{HASIL PENELITIAN}

\section{Hubungan Antara Panjang Tungkai Terhadap Hasil Lari 100 Meter}

Hubungan antara Panjang Tungkai Terhadap Hasil Lari 100 Meter dinyatakan oleh persamaan regresi $\hat{\mathrm{Y}}=1.83+0.91 \mathrm{X} 1$. Artinya hasil Hasil Lari 100 Meter dapat diketahui atau diperkirakan dengan persamaan regresi tersebut, jika variabel Panjang Tungkai $\left(\mathrm{X}_{1}\right)$ diketahui.

Hubungan antara Panjang Tungkai $\left(\mathrm{X}_{1}\right)$ terhadap hasil Hasil Lari $100 \operatorname{Meter}(\mathrm{Y})$ ditunjukan oleh koefisien korelasi ry1 $=0,69$. Koefisien korelasi tersebut harus diuji terlebih dahulu mengenai keberartiannya, sebelum digunakan untuk mengambil kesimpulan. Hasil uji koefisien korelasi tersebut dapat dilihat dalam tabel berikut :

Tabel 1. Uji keberartian koefisien korelasi

\begin{tabular}{lll}
\multicolumn{3}{c}{$\left(\mathrm{X}_{1}\right)$ terhadap $(\mathrm{Y})$} \\
\hline Koefisien korelasi & t.hitung & t.tabel \\
\hline 0.91 & 11.44 & 2.048 \\
\hline
\end{tabular}

Dari uji keberartian koefisien korelasi diatas terlihat bahwa t.hitung $=11.444$ lebih besar dari t,tabel $=2.048$ berarti koefisienkorelasi ry1 $=0,91$ adalah signifikan. Dengan demikian hipotesis yang mengatakan terdapat hubungan yang berarti antara Panjang Tungkai terhadap Hasil Lari 100 Meter. Koefisien determinasi Panjang 
Tungkai terhadap Hasil Lari 100 Meter (ry $1^{2}$ ) $=0.8238$ hal ini berarti bahwa $82.38 \%$ Hasil Lari 100 Meter (Y) ditentukan oleh Panjang Tungkai $\left(\mathrm{X}_{1}\right)$.

\section{Hubungan Antara Daya Ledak Otot Tungkai Terhadap Hasil Lari 100 Meter. \\ Hubungan antara Daya Ledak Otot} Tungkai terhadap Hasil Lari 100 Meter dinyatakan oleh persamaan regresi $\hat{Y}=2.96$ + 0.94 X2. Artinya Hasil Lari 100 Meter dapat diketahui atau diperkirakan dengan persamaan regresi tersebut, jika variabel Daya Ledak Otot Tungkai $\left(\mathrm{X}_{2}\right)$ diketahui. Hubungan antara Daya Ledak Otot Tungkai $\left(\mathrm{X}_{2}\right)$ terhadap Hasil Lari $100 \operatorname{Meter}(\mathrm{Y})$ ditunjukan oleh koefisien korelasi ry2 $=0,94$. Koefisien korelasi tersebut harus diuji terlebih dahulu mengenai keberartiannya, sebelum digunakan untuk mengambil kesimpulan. Hasil uji koefisien korelasi tersebut dapat dilihat dalam tabel berikut :

Tabel 2. Uji keberartian koefisien korelasi $\left(\mathrm{X}_{2}\right)$ terhadap $(\mathrm{Y})$

\begin{tabular}{ccc}
\hline $\begin{array}{c}\text { Koefisien } \\
\text { korelasi }\end{array}$ & t.hitung & t.tabel \\
\hline 0.94 & 14.68 & 2.048 \\
\hline
\end{tabular}

Dari uji keberartian koefisien korelasi diatas terlihat bahwa t.hitung $=14.68$ lebih besar dari t,tabel $=2.048$ berarti koefisien korelasi ry $2=0.94$ adalah signifikan. Dengan demikian hipotesis yang mengatakan terdapat hubungan yang berarti antara Daya Ledak Otot Tungkai $\left(\mathrm{X}_{2}\right)$ terhadap Hasil Lari 100 Meter (Y) diterima. Koefisien determinasi Daya Ledak Otot Tungkai terhadap Hasil Lari 100 Meter $\left(\right.$ ry2 $\left.^{2}\right)=0,8850$ hal ini berarti bahwa $88.50 \%$ Hasil Lari 100 Meter ditentukan oleh Daya Ledak Otot Tungkai $\left(\mathrm{X}_{2}\right)$.

\section{Hubungan Antara Panjang Tungkai Dan Daya Ledak Otot Tungkai Terhadap Hasil Lari 100 Meter. \\ Hubungan antara Panjang Tungkai} $\left(\mathrm{X}_{1}\right)$ dan Daya Ledak Otot Tungkai $\left(\mathrm{X}_{2}\right)$ terhadap Hasil Lari 100 Meter (Y) dinyatakan oleh persamaan regresi $\hat{\mathrm{Y}}=2.93+0.02 \mathrm{X}_{1}+$ $0.92 \mathrm{X}_{2}$. Sedangkan hubungan antara ketiga variabel tersebut dinyatakan oleh koefisien korelasi ganda Ry1-2 = 0,94 Koefisien korelasi ganda tersebut, harus di uji terlebih dahulu mengenai keberartiannya sebelum digunakan untuk mengambil kesimpulan. Hasil uji koefiesien korelasi ganda tersebut dapat dilihat dalam tabel berikut :

Tabel 3. Uji keberartian koefisien korelasi ganda

\begin{tabular}{ccc}
\hline $\begin{array}{c}\text { Koefisien } \\
\text { korelasi }\end{array}$ & F.hitung & F.tabel \\
\hline 0,94 & 103.91 & 4.08 \\
\hline
\end{tabular}

Uji keberartian koefisien korelasi di atas terlihat bahwa F.hitung $=103.91$ lebih besar dari F.tabel $=4.08$ yang berarti koefisien korelasi ganda tersebut Ry1-2 = 0,94 adalah signifikan. Hal Dengan demikian hipotesis yang mengatakan terdapat hubungan yang berarti antara Hubungan antara Panjang Tungkai $\left(\mathrm{X}_{1}\right)$ dan Daya Ledak Otot Tungkai $\left(\mathrm{X}_{2}\right)$ terhadap Hasil Lari 100 Meter (Y) diterima dan di dukung oleh data penelitian, yang berarti meningkatnya Panjang Tungkai dan Daya Ledak Otot Tungkai maka akan meningkatkan pula Hasil Lari 100 Meter (Y). Pada Hasil Lari 100 Meter $(\mathrm{Y})$. Koefisien determinasi $\left(\mathrm{Ry}_{1.2 .}\right)^{2}=$ 0,8850 hal ini berarti bahwa $88.50 \%$ Hasil Lari 100 Meter ditentukan oleh Panjang Tungkai dan Daya Ledak Otot Tungkai secara bersama-sama.

\section{PEMBAHASAN}

Berdasarkan dari hasil penelitian yang telah dilakukan, maka ditemukan hasil penelitian menunjukkan: pertama, terdapat hubungan yang berartti antara Panjang Tungkai terhadap hasil Lari 100 meter, dengan persamaan regresi $\hat{Y}=1.83+$ $0.91 X 1$. koefisien korelasi ry $1=0,69$, dan koefisien determinasi $\left(\right.$ ry $\left.^{2}\right)=0.8238$, yang berarti variabel Panjang Tungkai memberikan sumbangan terhadap hasil lari sebesar 82.38 $\%$. Kedua, terdapat hubungan yang berarti antara Daya Ledak Otot Tungkai terhadap 
hasil Lari 100 meter, dengan persamaan regresi $\hat{\mathrm{Y}}=2.96+0.94 \mathrm{X} 2$. Koefisien korelasi ry2 $=0,94$, koefisien determinasi $\left(\right.$ ry2 $\left.^{2}\right)=0,8850$ hal ini berarti Daya Ledak Otot Tungkai memberikan sumbangan terhadap hasil lari sebesar $88.50 \%$. Ketiga, terdapat hubungan yang berarti antara Panjang Tungkai dan Daya Ledak Otot Tungkai terhadap hasil Lari 100 meter. Dengan garis persamaan regresi $=2.93+0.02$ $\mathrm{X}_{1}+0.92 \mathrm{X}_{2}$, koefisien korelasi Ry1-2 $=0,94$, dan Koefisien determinasi $\left(\mathrm{Ry}_{1.2}\right)^{2}=0,8850$. Yang berarti Variabel Panjang Tungkai dan Daya Ledak Otot Tungkai memberikan sumbangan terhadap Hasil lari 100 meter sebesar $88.50 \%$.

Dalam penelitian ini Panjang Tungkai dan Daya Ledak Otot Tungkai secara Bersama-sama memberikan kontribusi sebesar $88.50 \%$ pada hasil Lari 100 meter. Untuk itu disarankan agar peneliti yang lain juga mencari faktor lain yang memberikan kontribusi yang baik terhadap Lari 100 meter.

\section{KESIMPULAN}

Berdasarkan hasil penelitian yang terdapat pada bab IV, maka peneliti dapat menarik kesimpulan sebagai berikut:

1) Terdapat hubungan antara panjang tungkai terhadap hasil lari 100 meter pada klub olahraga atletik pelajar jakarta utara dilihat dari hasil penelitian t.hitung $=11.444$ lebih besar dari t,tabel $=2.048$.

2) Terdpat hubungan antaradaya ledak otot tungkai terhadap hasil lari 100 meter pada klub olahraga atletik pelajar jakarta utara dilihat dari hasil penelitian t.hitung $=14.68$ lebih besar dari t,tabel $=2.048$.

3) Terdapat hubungan antara panjang tungkai dan daya ledak otot tungkai secara bersama - sama terhadap hasil lari 100 meter pada klub olahraga atletik pelajar Jakarta diliat dari hasil penelitian F.hitung $=103.91$ lebih besar dari F.tabel $=4.08$

\section{SARAN}

Berdasarkan kesimpulan dan hasil penelitian, maka dapat diajukan saran sebagai berikut:

1) kepada pemandu bakat agar dapat menentukan dan mengarahkan calon atlet berdasarkan kemampuan yang dimiliki terhadap cabang atletik khususnya melalui panjang tungkai dan daya ledak otot tungkai.

2) kepada pelatih agar dapat mengetahui dan melatih daya ledak otot tungkai sesuai dengan kemampuan atlet dilihat dari panjang tungkai sesuai dengan spesifikasi nomor lomba.

3) dalam cabang olahraga atletik seperti lari 100 meter, kemampuan fisik daya ledak sangat perlu di perhatikan. Salah satunya daya ledak otot tungkai yang berguna untuk melakukan perpindahan langkah sehingga waktu mencapai garis finish lebih cepat. selain itu diperlukan juga kualitas otot tungkai yang dapat memberikan tolakan pada saat start dengan hasil yang maksimal. Sesuai dengan hal tersebut maka disarankan agar pelatih memperhatikan kontribusi daya ledak otot tungkai dalam memberikan program latihan yang baik, karena seperti yang sudah peneliti bahas bahwa dalam lari 100 meter sangatlah diperlukan untuk mendapatkan waktu secepat - cepatnya dalam mencapai garis finish.

\section{DAFTAR PUSTAKA}

Djumidar A. Widya, Belajar Berlatih Gerakgerak Dasar Atletik Dalam Bermain. Jakarta : Raja Grafindo Persada, 2004.

Harsono, latihan Kondisi Fisik, Jakarta : komite Olahraga Nasional Indonesia Pusat, 1993.

Humaid, Hidayat. 2004. Jakarta : Jurnal ilmu kepelatihan. Jurusan somatokinetika.

James Tangkudung, Ilmu Faal. Jakarta: Cerdas Jaya, 2006.

Johansyah Lubis, Panduan Praktis Penyusunan Program Latihan. Jakarta : Raja Grafindo Persada, 2013. 
M. sajoto, pembinaan Kondisi Fisik Dalam Olahraga Jakarta : depdikbud, 1988.

Muhtar. (2011). Atletik. Bandung : CV warli artika.

Sajoto, Pembinaan Kondisi Fisik dalam olahraga. Jakarta : departemen Pendidikan dan kebudayaan, 1988.

Sudjana. Teknik Analisis Regresi Dan Korelasi. Bandung : Tarsito,1992.

Sugianto. Materi Pokok Perkembangan dan Belajar Gerak Jakarta:Depdikbud, 1991.
Suharno HP. (1985). Ilmu Kepelatihan Olahraga. Yogyakarta IKIP Yogyakarta.

Suharsimi Arikunto. Prosedur Penelitian, Jakarta : PT Rineka Cipta, 2006.

Sukadiyanto, dangsina muluk, Pengantar Teori dan Metodologi Pelatih Fisik, Bandung : CV Lubuk Agung, 2011.

Tudor O.B, Terjemahan Johansyah Lubis, Teori dan Metodologi Kepelatihan. Jakarta : UNJ, 2009. 